\title{
Forecasting of the dynamic impacts from planned railway route on environment
}

JEL: Q01 DOI: 10.24136/atest.2019.122

Data zgłoszenia: 05.04.2019 Data akceptacji: 26.06.2019

The paper presents the principles and methodology for analyzing the dynamic impacts from newly designed rail transport routes for high-speed rail. These type of interactions and, in particular, the nature of vibration propagation should be taken into account in any environmental opinion prepared for newly designed rail transport routes. The article presents the steps of assessment of dynamic impacts, which should be a basic methodology in the process of design and construction of rail transport routes.

Słowa kluczowe: ground vibrations, vibration monitoring, high speed railways.

\section{Wstęp}

Vibration hazards from rail transport should be considered at every stage of the project (planning, design, construction, maintenance and operation of rail transport routes). The aim should there- fore be to avoid errors that could have a negative impact on the environment and to minimise as far as possible the adverse effects of rail transport in the broad sense of this term. Assuming a priori that we are dealing with impacts adversely affecting the human environment, it is necessary to state that vibration is one of the most negative effects of rail transport which pollutes the natural environment. At this point it should be noted that rail transport may pose a relatively small threat to the environment, provided that the railway subgrade is properly constructed and the surface is appropriately maintained. Particularly dangerous are vibrations caused by communication for historic buildings located mainly in historical city centres, at narrow streets, on grounds with unfavourable strength properties. This analysis was carried out on the example of a newly designed railway route running from Łódź Fabryczna station to Łódź Kaliska station in a tunnel under the historic centre of Łódź. The basic assumption is to minimize the harmful impact of railway transport on the construction infrastructure located above the tunnel, which should lead to the creation of new solutions for subgrades of railway vehicles with limited vibroacoustic emission, as

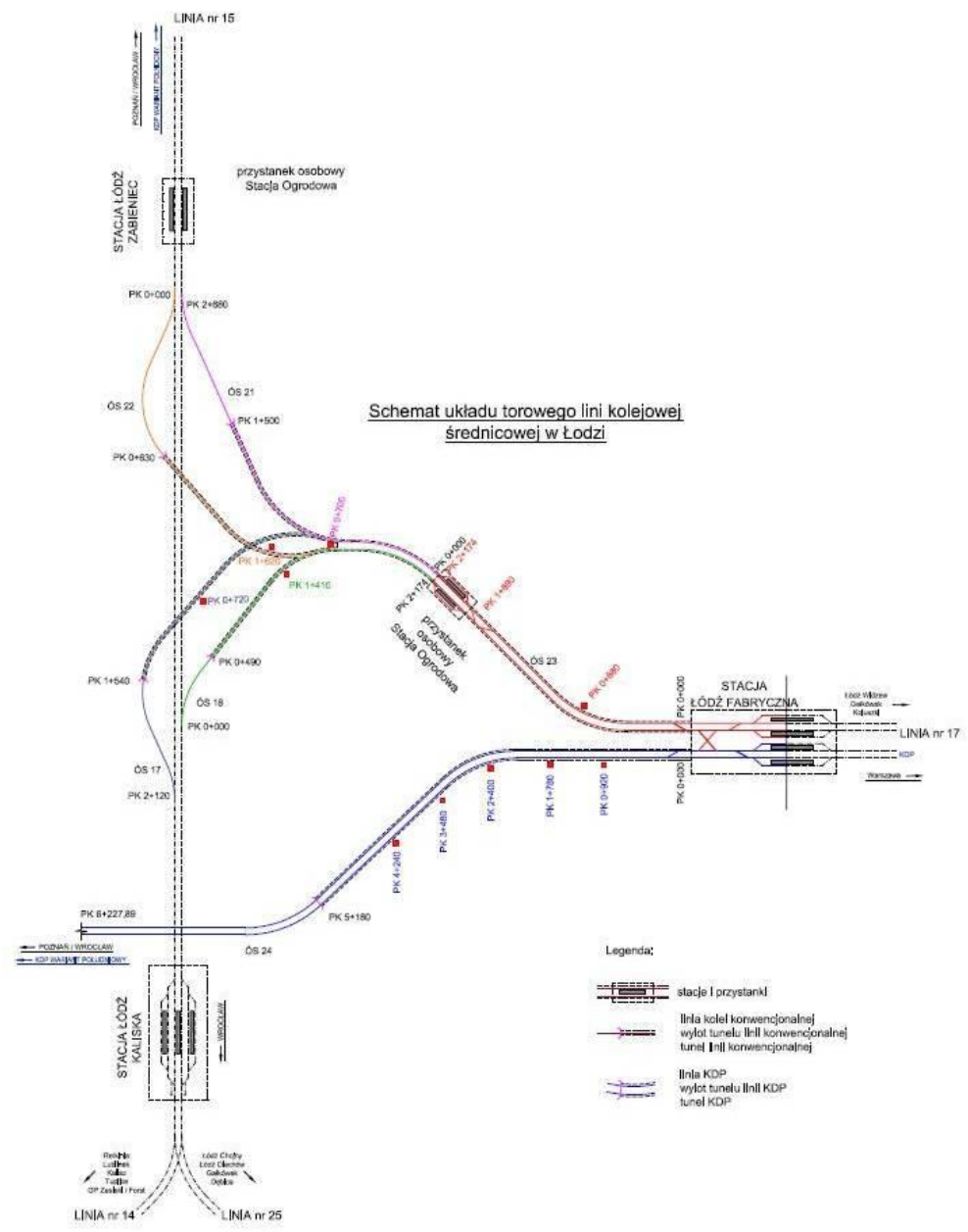

Fig. 1. Diagram of the selected solution of the HSR route and conventional rail routes [1] 
well as the use of complex vibro-insulation systems of railway subgrades, which are an obstacle to the spread of vibrations to the environment.

All this, however, requires the development of an environmental opinion from the point of view of the dynamic impact on the environment of the newly designed rail transport route.

\section{Preliminary technical analyses of the possibilities of investment implementation}

At the initial stage it is necessary to obtain reasonably accurate data on what is the subject of the project. Whether the construction is to be carried out in an open area or in an urban agglomeration. For example, in case of the newly designed Łódź line which has to connect the Łódź Fabryczna station with the Łódź Kaliska station, the scope of design solutions concerning the possibility of laying a cross section line in the Łódź area is mainly due to technical and spatial conditions and the specific location of the Łódź Fabryczna station resulting from the historical development of infrastructure in Łódź at the turn of the 19th and 20th centuries. They must have had a significant impact on the design works, which concerned the reconstruction of the Łódź Fabryczna - Koluszki railway line between Łódź Widzew and Łódź Fabryczna. The adopted solutions concerning the spatial and functional layout of the station determined the possibility of running the high speed railway line (HSR) and the cross section line within the Łódź Railway Junction, as well as allowed to obtain new quality conventional passenger railway connections passing through the Łódź junction serving interregional, regional and agglomeration traffic. An important element is the possibility of obtaining connections with any elements of the railway infrastructure of the Łódź junction in order to enable the maintenance of HSR trains and conventional trains ending and starting in Łódź, and thus improving the quality of services for passengers.

At the stage of preliminary technical analyses it was necessary to define several variants of the route of the cross section line and the HSR line. For all these variants, technical analyses and comparative analyses related to the assessment of advantages and disadvantages of the presented solutions had to be and were carried out. Based on the "Feasibility study of a railway line from Łódź Fabryczna station towards Łódź Kaliska station", the main element of which was a cross section tunnel with underground stops and a HSR tunnel. The routes of HSR tunnels were a development of the proposals presented in the aforementioned study, out of which variant 14 presented in Figure 1 was adopted for further studies.

A detailed analysis has identified the advantages and disadvantages of this route concept. The advantages of this solution include:

1. Travel along the significant distance through areas with a low degree of urbanisation in relation to other solutions,

2. The shortest length of newly designed tunnels,

3. Avoidance of crossings with conventional rail tunnel routes.

4. Quite convenient location of the junction in the area of the city border with the railway line and the planned expressway No. S14,

5. The route along a significant section of the corridor already occupied for transport purposes,

6. Minimizing the number and degree of difficulty of collisions with roadways,

7. Small collision with city urbanisation,

8. Relatively low probability of generating potential social conflicts. The disadvantages of this solution are:

1. Collisions with canalised rivers and deep sewers.
2. Difficulties in locating potential HSR stops,. Need to cross twice with the existing railway line no. 14 .

3. In case of the construction of a tunnel using the open-pit method, it is necessary to provide an appropriate substitute transport (bus) or to put a part of a temporary tram route.

4. Passages through forest areas.

5. The need to cross the valley of Ner River.

6. Collision with respect to the predicted location of the trigger point for supplying Lublinek airport with aviation fuels and construction of a railway siding.

7. The need to build a large track and road system on the city border.

Taking into account the advantages and disadvantages and carrying out analyses of all variants of the newly designed HSR route, it could be concluded that regardless of the problem concept, the spread of dynamic impacts is almost identical for all variants when it comes to limiting their impact on buildings and the people staying there. This is important as in the first period of operation, when the line is put into operation, para-seismic impacts may be unnoticeable. However, it is probable that after a period of several or more years they may lead to significant damage to the historical infrastructure of buildings. Therefore, vibration isolation and its proper selection and maintenance are necessary.

\section{Characteristics of the planned project impact on the environment}

Vibration hazards should be considered at every stage (planning, design, construction, maintenance and operation of rail transport routes), so that errors that may adversely affect the environment should be avoided and, as far as possible, the adverse effects of rail transport in the broad sense of the term should be minimised. Assuming a priori that we are dealing with impacts adversely affecting the human environment, it is necessary to state that vibration is one of the most negative effects of rail transport which pollutes the natural environment. Vibrations are a nuisance of widespread social range and occur in all areas of human activity, affect all citizens, adversely affect their health, hinder their rest and regeneration, reducing the effects of their work and increasing the likelihood of accidents at work. Research and literature analyses show that they affect about 30 - $40 \%$ of our society population and their source is mainly transport (railway, tramway, cars, air and sea transport). Occupants of large urban agglomerations and cities of an industrial character are particularly exposed to vibrations, because there is a high traffic volume of means of transport carrying out transport of raw materials and export of manufactured products. The same cities are additionally burdened with vibrations from public transport and private vehicles. At this point it should be noted that rail transport may pose a relatively small threat to the environment, provided that the railway subgrade is properly constructed and the surface is appropriately maintained. Vibrations have a significant impact on the construction of buildings, causing damage, which results in more frequent renovations, and in extreme cases, as a result of public services' negligence, can lead to a construction disaster. Particularly dangerous are vibrations caused by communication for historic buildings located mainly in historical city centres, at narrow streets, on grounds with unfavourable strength properties. As a result of the propagation of vibrations in the ground, the functional usefulness of such public buildings as hospitals, schools, residential buildings is also deteriorating (vibrations transmitted to the residents' organism). It should also be mentioned that vibrations are the source of noise emission, which has a harmful effect on the human body or causes unfavourable feelings concerning mental comfort. Since broadly understood transport is inherently accompa- 
nied by the dynamic impact, especially within areas occupied by road and railways, causing vibrations of various types of engineering structures [6], the aim to minimize their harmful effects is a necessity and must lead to the creation of new solutions for equipment and facilities involved in road and rail transport with limited vibroacoustic emission as well as complex vibration-insulation systems constituting an obstacle to the spread of vibrations to the environment. Therefore, first of all, the analysis of the potential vibration risk should start with the determination of the sources of vibrations that are components of the dynamic background, regardless of whether the construction project will be implemented or not.

On the example of the newly designed tunnel of the HSR railway route from Łódź Fabryczna station to Łódź Kaliska, it was stated that the following transport groups are the main source of vibrations occurring along the entire route:

1. vibrations of passenger cars and vans,

2. vibrations of public transport buses,

3. vibrations of lorries - exit routes to Katowice, Gdańsk, Warsaw,

4. rail transport - trams.

The next stage is the determination of dynamic impacts during the construction and exploitation phase.

In the phase of investment implementation - during tunnel works, it is necessary to predict the occurrence of significant sources of vibrations, which may have an impact on the construction of buildings. The source of such vibrations may be:

1. construction works carried out in form of boreholes

2. driving sheet piling walls (steel bulkheads or piles) into the ground,

3. compaction of soil or road surface layers with vibration rollers, etc.

These works may cause damage to buildings and should be monitored (vibration measurements) for the effect of vibrations on the structure of the nearest buildings. On the basis of these vibration measurements, it is necessary to determine the distances and operating parameters of individual devices (vibratory hammers, vibration rollers) so as to exclude the possibility of damage in the closest neighbouring buildings. It should be assumed that due to the limited time of occurrence of these vibrations (which should be coordinated in accordance with the standard), it will be possible to allow for temporary exceeding of the comfort limit during the day in relation to the influence of vibrations on people staying inside buildings (these works should not be carried out at night in any case).

Temporarily, there may be a worsening of conditions with regard to the influence of vibrations on people staying in the buildings (violation of the required comfort requirements) located near the access routes to the construction sites, especially during the passage of trucks with exported soil and delivering concrete. When locating construction sites and determining the access routes of heavy goods vehicles, it is advisable to take into account the issues of equal protection against vibrations as well as the level of noise emission.

During the operation of the HSR tunnel, the main source of vibrations transmitted to the environment are railway movements. Moreover, to a much lesser extent, the vibrations may be caused by the operation of equipment such as: fans (vibrations in the environment of air conditioning fans), pumps in pumping stations, aggregates, etc. The intensity of vibrations transmitted to neighbouring buildings and connected with HSR train traffic depends on:

1. The construction and condition of the rolling stock (especially the condition of wheel sets, e.g. excessive radial run-out of the wheels may cause a multiple increase in the level of vibrations),

2. The structure and condition of the rail surface (number and construction of rail joints, rail surface, rail fastening to the rail- way subgrade, tolerances of rail track sides in the plan and profile),

3. The method of movement of the train (speed, track - straight or curved, stopping and moving)

4. Construction of the subgrade,

5. The structure of the tunnel casing (type of structure, type of material, mass, damping) through which vibrations propagate to the outside and which interacts with the ground adjacent to it,

6. Tunnel cavities, including the relationship between tunnel cavity and level of buildings foundation,

7. Type and condition of the substrate through which vibrations propagate: geotechnical structure of the substrate, water conditions in the substrate, presence of partitions and crevices, underground infrastructure, etc,

8. Distance and location of buildings receiving vibrations in relation to the HSR tunnel,

9. Type and condition of the building receiving vibrations: type of building, its structure and geometry, method of foundation, condition of building preservation, dynamic characteristics of the structure (natural vibrations frequency, damping),

Therefore, the proposed methodology of evaluation of vibration influence should be based on:

1. Evaluation of the influence of vibrations on the structure of the building located near the passage routes of the HSR railway lines,

2. Evaluation of the impact of vibrations on people inside buildings,

3. Evaluation of the effect of vibrations on equipment sensitive to vibrations, if such equipment is or will be present in the building,

4. Evaluation of vibration wave propagation.

This assessment can be carried out on the basis of vibration measurements of existing objects and determination of their condition of danger according to norms and theoretical methods, forecasting the state after the completion of implementation. The standards include legal bases and detailed regulations concerning the evaluation of vibration influence in the above cases are included in the Polish standards:

1. PN-85/B-02170 entitled "Evaluation of the harmfulness of vibrations transmitted by the ground to buildings",

2. $P N-88 / B-02171$ entitled "Evaluation of the impact of vibrations on people inside buildings",

3. PN-80/B-03040 entitled "Foundations, supporting structures for machines. Calculations and designing."

The PN-85/B-02170 standard provides two ways to assess the influence of vibrations on the building structure:

1. full assessment - applicable to each type of building,

2. approximate assessment (using SWD-I and SWD-II dynamic impact scales) - it can only be used for two building classes specified in the standard.

This assessment should be complemented by an analysis of the impact of vibrations on building structures, carried out in accordance with the principles of building dynamics. Detailed rules of dynamic calculations of structures are given in PN-85/B-02170 standard and in norms and manuals on building dynamics.

In case of developing a prognosis of dynamic interaction, the newly designed rail or automobile communication routes require the use of a simplified model or a model developed on the basis of the finite elements method (FEM) of the subsoil or building structure on the basis of which dynamic simulations of wave propagation in the ground and the response of engineering structures to extortion are carried out $[3,4,7]$. Enforcement can be taken into account either by applying at the points of contact between the foundation and the substrate, kinematic excitation described by time courses of vibrations (measured or predicted vibrations) of the foundations, or by 
means of the so-called reverse problem. The assessment consists in determining the possible natural frequencies of engineering structures and checking the possibility of resonance, determining the inertia forces acting additionally on the structure under the influence of vibrations, loading the design model of the structure with all static and dynamic loads (inertia forces, wind pressure, etc.) and checking the such loaded structure in terms of strength.

As mentioned above, it is necessary to use the finite element method as a tool for the predictive assessment. Application of the finite element method allows for the analysis of the behaviour of buildings when trains pass $[2,5]$. Such an analysis includes the determination of a number of physical values, which can be used to assess the impact of vibrations on any building structure. Such values may include, first of all, acceleration at any measuring point on the building as well as speed, displacement or stress. Comparison of these values with generally available criteria and standards at the tunnel design stage allows for appropriate modifications of structures in order to reduce the values occurring in buildings. Such modifications primarily concern the use of appropriate vibration isolation in form of e.g. mats laid in the track layer or rail pads. This approach to the design process is important because of the enormous complexity of such structures, which makes it largely impossible to make additional modifications after completion of the works due to, among other things, costs and time.

Correct execution of the simulation requires careful preparation of a numerical model and a series of input data. Preparation of the model includes appropriate selection of the size of finite elements, determination of the size of the model (mainly soil area), application of appropriate boundary conditions that prevent the reflection of vibrations from the extreme nodes. Input data concerns mainly accurate material data concerning both buildings, tunnel and soil.
The soil may include various types of sands (fine sands, silt sands, clay sands), clay (sandy, rocky), gravel, loess, etc. Each of these layers is characterized by different strength properties and different levels of attenuation.

The simulation of a train passage requires precise knowledge of the basic parameters of the rolling stock such as maximum speed, maximum axle press, number of wagons in the rolling stock and the basic geometrical dimensions (wagons base, length of wagons, etc.) allowing to determine in detail the moment of passage of a given wheel set through the tracks. Such data allow to prepare the spectrum of loading forces on the simulated section of tracks. Additionally, it is possible to take into account the unevenness of the tracks on the basis of other tracks, which is the cause of the greatest vibrations forced by the passing train. Figure 2 shows a model configuration for the planned tunnel in Łódź, taking into account such parameters as: tunnel foundation depth, tunnel geometrical dimensions, depth of the building below and above ground level and the wall layout of the building.

Figure 3 shows an exemplary result of acceleration simulation for two measurement points on the building located under and above ground level.

This approach was characterised by the implementation of research work carried out in the following years of 1980-2009 in which measurements of trackway vibrations and propagation of vibration waves were carried out on the following railway and tram lines, among others:

1. Central Railway Arterial Road on the Psary Tunel section,

2. Route E20 of Warsaw-Kunowice,

3. Measurements of vibrations in Kraków, Łódź and Bydgoszcz, as well as evaluation and prognosis of the influence of dynamic impacts from tramway vehicles,

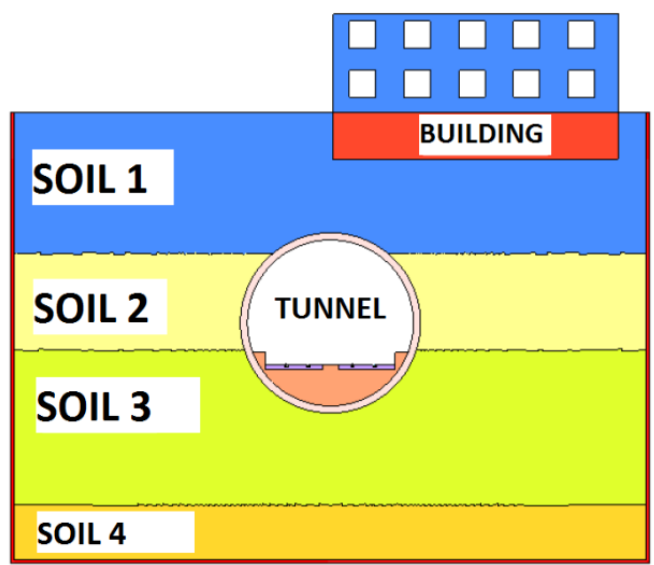

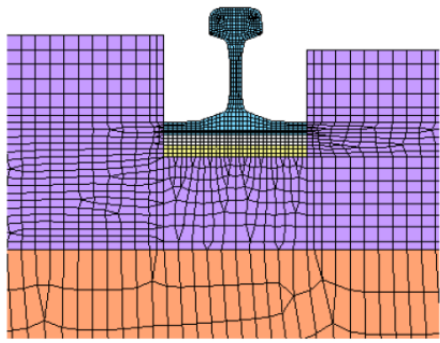

Fragment of a tracks line model

Fig. 2. Example of a numerical model with an enlarged fragment of the finite element grid [1].

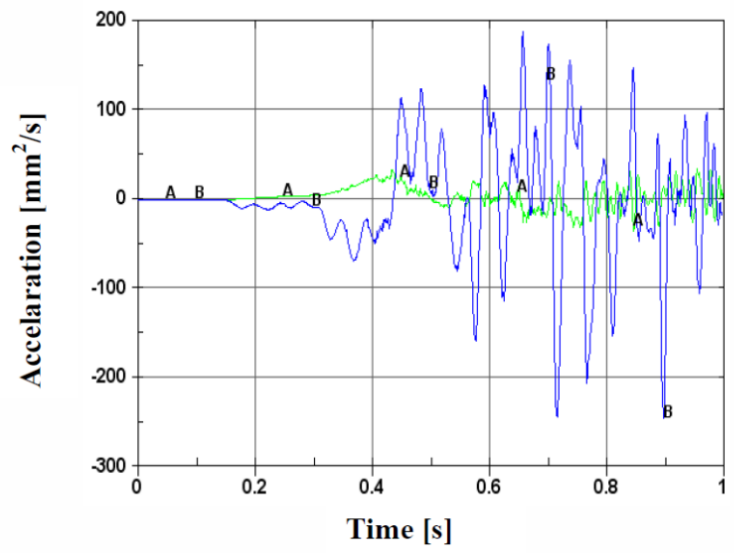

A - level (-2) [m] under ground

$\mathrm{B}$ - level $1[\mathrm{~m}]$ upper ground

Fig. 3. Example of the building's acceleration course [1] 
4. Railway and road crossings in Trzebinia and Lubin.

In order to fully assess the environmental impact of vibrations from rail and automotive vehicles, continuous monitoring should be carried out on the being constructed and then operated investment.

\section{Monitoring of the impact of the planned project at the stage of construction and operation}

Due to the safety of residential buildings and residents located in Łódź near the planned railway line, the following concepts of building vibration monitoring have been presented. It was assumed that it is to meet the safety standards included in the PN-85/B02170 and PN-88/B-02171 standards. Two alternative solutions for building vibration monitoring have been proposed:

1. Direct monitoring of building vibrations through the installation of vibration sensors on each building above or in the immediate vicinity of the HSR tunnel line along the entire section,

2. Indirect monitoring of building vibration through the installation of vibration sensors along the HSR tunnel line.

The first solution allows to create a complete building vibration map directly from measurements made on buildings. In such an approach, the cost of installing sensors, the number of which would be a multiple of the number of monitored buildings depends on the building permits (apart from the price of appropriate electronic systems) for the possibility of installing a vibration monitoring system.

In the second solution, a building vibration prognosis is obtained on the basis of vibrations of the railway subgrade. The solution would assume the installation of sensors along the tracks of the HSR tunnel line in places located in the immediate vicinity of the buildings, the vibrations of which will be measured. Vibration measurement would be carried out on the basis of mathematical models of soil around the subway. Such models are developed and tested.

Estimation of dynamic impacts should be carried out at each stage of project implementation, i.e. at the stage of planning, execution and operation.

\subsection{Estimation of dynamic impacts at the planning stage}

In case of planning the construction of HSR routes in densely built-up areas, it is recommended to perform the detailed analyses and expertises in the scope of resistance of construction structures to dynamic impacts that may arise during the construction of the route. The scope of this work should include:

1. Inventory of sources of construction machinery and equipment vibrations and determination of the range of zones of their influence,

2. Assessment of the influence of these vibrations on construction objects in the dynamic influence zone,

3. Carrying out (prior to the commencement of construction works) an inventory of damages to buildings located in the area of influence of particular sources of vibrations from construction machines and equipment,

4. Determination of those cases in which it is necessary to perform vibration measurements on the construction works and determining on this basis the possibility of performing construction works and possible ways of protecting the construction works against vibrations caused by these works (e.g. selection of working parameters for the equipment in order to minimize the impact of vibrations on the structure),

5. Designing the vibroisolation of the railway subgrade on the basis of conducted prognoses,

6. Detailed designs for securing these endangered construction works
7. Development and implementation of a system for monitoring the impact of vibrations on building structures located in the immediate vicinity of the investment.

\subsection{Monitoring of vibrations at the execution stage}

It is necessary during the execution of the investment:

1. Periodic examination of the dynamic background, i.e. the dynamic influence on the existing buildings resulting from the construction works,

2. In case of emerging risks to existing construction infrastructure, protecting their structure against damage.

\subsection{Monitoring of vibrations at the operation stage}

Recommended scope of work before operation:

1. Monitoring of the technical condition (damages) of buildings located in the zone of dynamic impacts from the HSR route,

2. Study of changes in the dynamic background, i.e. dynamic influences on the existing buildings coming from a new source of vibrations - railway traffic,

3. Analysis of the influence of vibrations on the existing buildings caused by the operation of the investment in the following scope:

4. Simulation calculations of the influence of vibrations and determination of the predicted level of these influences,

5. A proposal for protection for cases where this is required,

6. Performance of control measurements of vibrations of buildings on individual sections of the investment.

On the basis of the presented considerations, it should be stated that during the operation of the HSR line it is recommended to constantly monitor the dynamic effects of railway traffic on the construction objects located in the direct vicinity of the railway line.

\section{Summary}

Analyzing the results of the research carried out by the author, it can be stated that due to the fact that in the analyzed investment the tunnel will run directly under the buildings, it is necessary to develop detailed expert opinions relating to these buildings, especially with regard to their resistance to vibrations both at the stage of construction and operation. For each case where negative impacts have been identified, a detailed design of vibration protection for these buildings should be developed. The diagnosis concerning the assessment of the impact of vibrations on the environment of newly designed railway, tramway and car investments should include:

1. Analysis of possible routes,

2. Measurements of vibrations on the route accepted for the realization,

3. Simulation of the vibrations impact on the environment and engineering structures at both the construction and operation stages,

4. Monitoring during construction as well as after its completion.

Bibliografia

1. Adamczyk J., Targosz J., Stryczniewicz L. ,Brożek G., Raport o oddziaływaniu na środowisko planowanego przedsięwzięcia dotyczącego budowy linii kolejowej, na odcinku od dworca Łódź Fabryczna w kierunku dworca Łódź Kaliska do linii nr 14 i 25 oraz linii 15, której głównym elementem jest tunel średnicowy z podziemnymi przystankami oraz tunel KDP, opracowanie firmy Inter-Eko Sp. z o.o. Kraków, listopad 2011.

2. Bednarz J., Targosz J., Eksperymentalna analiza rozchodzenia się drgań w gruncie wywołanych przejazdem pojazdów szynowych, Logistyka, nr 6, str. 153-160, 2011. 
3. Bednarz J., Targosz J., Experimental verification of the developed soil model describing the propagation of vibration wave in the ground, Journal of KONES Powertrain and Transport, vol. 19, no. 3, str. 31-39, 2012.

4. Bednarz J., Targosz J., Finite elements methods in analisis of propagations of vibrations wave in the soil, Journal of KONES Powertrain and Transport, vol. 18, no. 3, str. 19-25. 2011.

5. Bednarz J., Zastosowanie metody elementów skończonych $w$ analizie drgań gruntu, TTS - Technika Transportu Szynowego, nr 9, str. 2215-2222, 2012.

6. Ciesielski R., Maciag E., Drgania drogowe $i$ ich wpływ na budynki, WKŁ, Warszawa 1990.

7. Hassen G, de Buhan P, Abdelkrim M., Finite element implementation of a homogenized constitutive law for stone columnreinforced foundation soils, with application to the design of structures, Computers and Geotechnics, vol. 37, str. 40-49, 2010.

\section{Prognozowanie oddziaływań dynamicznych od planowanej trasy kolejowej na otoczenie}

W pracy przedstawiono zasady i metodologię postępowania w przypadku szacowania oddziaływań dynamicznych od nowoprojektowanych tras komunikacji szynowej dla kolei dużych prędkości. Tego typu oddziaływania a w szczególności zagrożenia natury drganiowej winny być uwzględniane w każdej opinii środowiskowej dotyczącej nowoprojektowanych szlaków komunikacyjnych. W artykule przedstawiono kolejne etapy oceny zagrożeń dynamicznych, które powinny być stanowić podstawową metodologię przy projektowaniu i budowie tras komunikacji szynowej.

Słowa kluczowe: drgania gruntu, monitoring drgań, koleje dużych prędkości.

Autor:

dr inż. Jarosław Bednarz - AGH Akademia górniczo-Hutnicza, Katedra Robotyki i Mechatroniki, al. Mickiewicza 30,30-059 Kraków; e-mail: bednarz@agh.edu.pl 